\title{
VIKTOR BARVITIUS - A MUSEUM MAN FROM PRAGUE TOURS THE PICTURE GALLERIES IN DRESDEN, BERLIN AND MUNICH IN 1883
}

\section{MARIA OBENAUS}

Modern museums are faced with a variety of challenges and needs: How can a diverse audience be reached? How can an object be presented best? What contextual information needs to be given? Or: How can the safety of the artworks be ensured? These questions have been asked before, as personal records of the Prague gallery inspector Viktor Barvitius (1834-1902) prove. The Society of Patriotic Friends of the Arts commissioned him with the establishment of the Prague Picture Gallery in the new building of the Rudolfinum, the predecessor of today's Národní galerie. In order to find out about the state of the art of all practical aspects of the museum business, Barvitius travelled to Vienna in 1882 and again in January 1884, and to Dresden, Berlin and Munich in August and September of 1883. He visited the numerous galleries, consulted with museum directors and restorers, studied visiting regulations, documented the condition of individual paintings and observed everyday museum life.

Barvitius spent ten days in Dresden before traveling on to Berlin and Munich. What makes his journey special is the fact that he described his observations in detail on 90 manuscript pages and added numerous sketches. The records, written in German, are kept at the archives of the Národní galerie in Prague. ${ }^{1}$ A report, in which he summarized the results for the committee of the Society of Patriotic Friends of the Arts, and a detailed accounting of the costs of his trip complete the document. ${ }^{2}$ The expenses for rail travel, hotel accommodations, meals, entrance fees, and tips in the individual cities allow us to follow Barvitius on the individual stages of his journey.

The travel records provide insights into everyday museum life, that are rarely mentioned in research: Barvitius tells about guiding and educating museum visitors, the paintings' hanging, gallery labels, picture frames, and the dealings with depot holdings. Restoration issues play a role, as does the use of gallery furniture, railings, and curtains. With the thoroughly gathered information, he wanted above all to find out how the collection in Prague could best be secured and presented.

The comparison reveals certain changes, such as the fact that in Dresden admission fees were charged on single weekdays as early as the 1850s, while the museums in Berlin and Munich could be visited free of charge until the beginning of the 20th century. Thanks to

\footnotetext{
1 Archiv Národní galerie v Praze, fond: Viktor Barvitus, Sign. AA 1177. Viktor Barvitius, Záznam o cestě do Drážd’an, Berlína a Mnichova (něm.), 1883.

2 Archiv Národní galerie v Praze, fond: Společnost vlasteneckých přátel umění, Sign. AA 1059. Zpráva Viktora Barvitia o cestě do Drážd’an (něm.), 1883.
}

Barvitius, it is documented that Munich collected 20 pfennigs for wardrobe storage in the 1880 s, while the Berlin museums did not ask for a wardrobe fee, although it was "kindly accepted" there. ${ }^{3}$ The Gemäldegalerie in Dresden maintained a record of the annual number of visitors: In the $1880 \mathrm{~s}$, they rose from 160,000 to 280,000 . The galleries became popular places to visit not least because of the new heating systems, in which Barvitius was particularly interested.

In the period before the gallery buildings were electrified, safety precautions were challenging: In Dresden, "two guards from the porcelain collection [...] were on night watch duty; in addition, military guards monitored from outside." ${ }^{4}$ In the Gemäldegalerie Berlin, Barvitius was impressed by the use of the automatic fire extinguishers; in Munich, smoking was forbidden, although "the director and the curator in his own room did not pay any attention to this rule. ${ }^{5}$ Comments like these

\footnotetext{
3 Aufzeichnungen des Prof. Barvitius über seine Reise nach Dresden, Berlin u. München/Zápisky profesora Barvitia z jeho cesty do Drážd’an, Berlína a Mnichova. Online-Edition einer Schlüsselquelle zur deutsch-böhmischen Museumsgeschichte des späten 19. Jahrhunderts./Online vydání klíčového pramene $k$ dějinám německo-českého muzejnictví konce 19. století [online]. Dresden: Staatliche Kunstsammlungen Dresden, Praha: Národní galerie v Praze, 2020, as footnote 1, p. 37 [accessed 2021-02-15]. Available from www: <https://doi.org/10.11588/arthistoricum.749> The quotes were translated by the author of this article.

4 Ibid, p. 40

5 Ibid, p. 42.
} 
make the source so unique. In addition, Barvitius hardly omits a single topic, not even detailed observations on the Dresden Kupferstich-Kabinett - the collection of prints and drawings, at that time housed in the Semper Building with a public study room. As a result, improvements were immediately implemented at the Rudolfinum. They included the spatial separation of the drawings from the prints as well as their presentation in showcases.

In the 1870s and 1880s one still generally read: "Children under 10 years of age are not admitted." The visitor regulations of the Berlin Royal Museums stated that museum admission was "permitted to anyone decently dressed." The shared use of the gallery spaces by copying artists, art experts, the educated upper classes and the wider public also led to conflicts. Thus, around the turn of the century, it became the core task of the gallery directors to meet the different demands that were placed on the use of the museums with appropriate and often quite mundane means.

Barvitius' observations and their implementation in Prague are an outstanding example of European exchange and a valuable source for future research. The Picture Galleries in Dresden, Berlin, and Munich each emerged from royal holdings and developed in the

\footnotetext{
6 Archiv Staatliche Kunstsammlungen Dresden, 01 GG Nr. 12 Bd. 1, Bl. 11, § 4. Regulativ für den, Besuch und die Benutzung der Königlichen GemäldeGalerie, 1 May 1873. See also Aufzeichnungen des Prof. Barvitius über seine Reise nach Dresden, Berlin u. München/Zápisky profesora Barvitia z jeho cesty do Drážd’an, Berlína a Mnichova. Online-Edition einer Schlüsselquelle zur deutsch-böhmischen Museumsgeschichte des späten 19. Jahrhunderts./ Online vydání klíčového pramene $k$ dějinám německo-českého muzejnictví konce 19. století [online]. Dresden: Staatliche Kunstsammlungen, Praha: Národní galerie v Praze, 2020, as footnote 1, 1883, p. 39 [accessed 2021-02-15]. Available from www: <https://doi.org/10.11588/ arthistoricum.749>

7 Vossische Zeitung, No. 78, 2. 4. 1870.
}

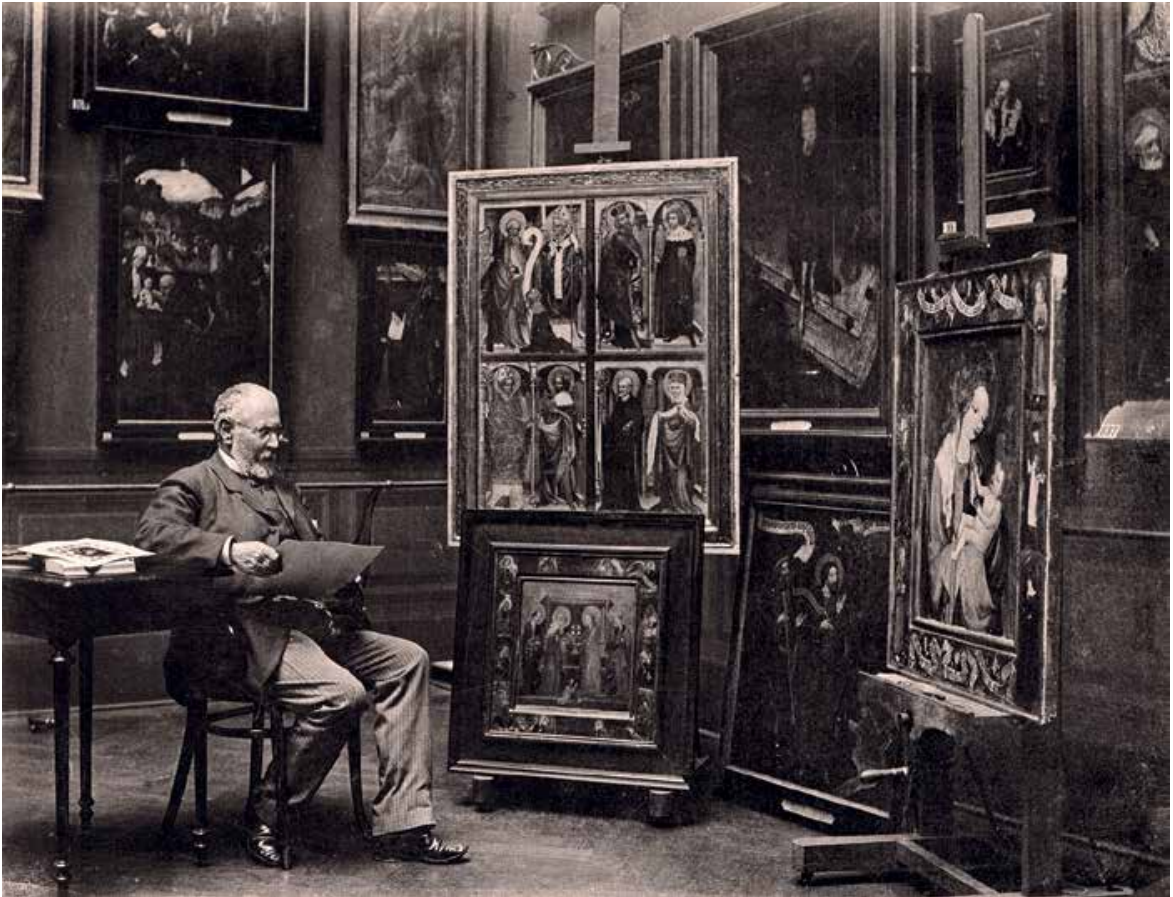

Fig. 1: Viktor Barvitius in the Rudolfinum in Prague, 1893, Archiv Národní galerie v Praze, Viktor Barvitius, 1864-1902 (1932), inv. No. 18.

course of the 19th century into visitor-oriented institutions with independent gallery buildings and a competent and increasingly critical public. Barvitius was able to tie in with these developments. Thus, the establishment of the Prague Picture Gallery coincides with a period of professionalization in all areas of the museum system. Barvitius himself was a painter; his colleagues already came from the circle of art historians. Restoration techniques were based on new insights into the effects of temperature, light and dust. Targeted educational offers led to the start of museum education activities.

The publishing of the manuscript and the essays by Czech and German authors was possible thanks to the funding of the Česko-německý fond budoucnosti and the cooperation between the Staatliche Kunstsammlungen Dresden and the Národní galerie v Praze, which has been intensified since 2017. In addition, the unique source appears as a transcription and in Czech translation in open access at arthistoricum and is intended to provide input for further research. The publication is dedicated to Gilbert Lupfer, Head of the Department for Research and Scientific Cooperation and of the Daphne-Project in Dresden, who celebrated his 65 th birthday in November 2020.

\section{BIBLIOGRAPHY:}

Archiv Národní galerie v Praze, fond: Společnost vlasteneckých přátel umění, Sign. AA 1059. Zpráva Viktora Barvitia o cestě do Drážd’an (něm.), 1883.

Archiv Národní galerie v Praze, fond: Viktor Barvitus, Sign. AA 1177. Viktor Barvitius, Záznam o cestě do Drážd’an, Berlína a Mnichova (něm.), 1883.

Archiv Staatliche Kunstsammlungen Dresden, 01 GG Nr. 12 Bd. 1, Bl. 11, $\S$ 4. Regulativ für den Besuch und die Benutzung der Königlichen GemäldeGalerie, 1 May 1873.

Aufzeichnungen des Prof. Barvitius über seine Reise nach Dresden, Berlin u. München/ Zápisky profesora Barvitia z jeho cesty do Drážd’an, Berlína a Mnichova. Online- 


\section{MUSEOLOGICA BRUNENSIA}

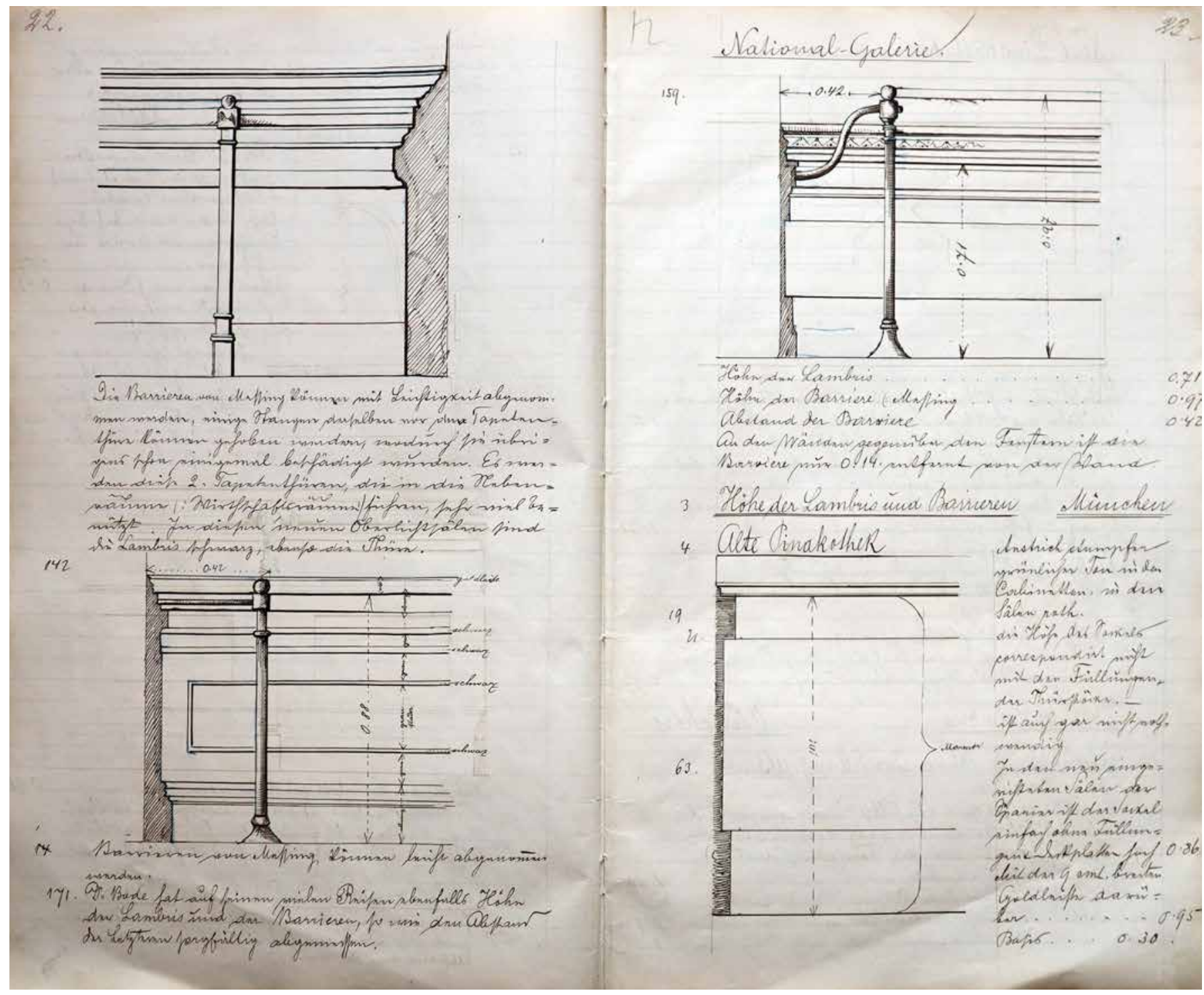

Fig. 2: Viktor Barvitius, handwritten records of his journey to Dresden, Berlin and Munich, 1883, Archiv Národní galerie v Praze, Viktor Barvitus rukopisy, Sign. AA 1177 , p. 22 and 23.

Edition einer Schlüsselquelle zur deutschböhmischen Museumsgeschichte des späten 19. Jahrhunderts./Online vydání klíčového pramene $k$ dějinám německo-českého muzejnictví konce 19. století [online]. Dresden: Staatliche Kunstsammlungen Dresden, Praha: Národní galerie v Praze, 2020 [accessed 2021-02-15]. Available from www: <https://doi.org/10.11588/ arthistoricum.749>.

HÜSGEN, Jan, Romy KRAUT and Maria OBENAUS (eds.). Zur Einrichtung von Gemäldegalerien. Die Aufzeichnungen von Victor Barvitius aus Prag über seine Reise nach Dresden, Berlin und München 1883. Dresden, Prag: Staatliche Kunstsammlungen Dresden,
Nationalgalerie in Prag, 2020.

ISBN: 978-3-95498-577-7.

Vossische Zeitung, No. 78, 2. 4. 1870.

\section{MARIA OBENAUS}

Staatliche Kunstsammlungen Dresden, Dresden, Germany maria.obenaus@skd.museum 
